\title{
BIOGRAFISTYKA JAKO ARCHEOLOGIA RUIN
}

\section{BIOGRAPHICAL WRITING AS ARCHAEOLOGY OF RUINS}

\author{
Izolda Kiec \\ orcid.org/ 0000-0001-7715-1550 \\ Uniwersytet Artystyczny w Poznaniu \\ Aleje Marcinkowskiego 29, 60-967 Poznań \\ izolda.kiec@uap.edu.pl
}

\begin{abstract}
The article is devoted to biographical writing, which by the methodologies of the 20th century was thrown out of the field of humanities research. It returns in the new century with cultural anthropology, gender studies and - above all - memory studies. However, it raises a lot of questions, including doubts about the representation (author of the biography) and witnesses of events. The author of the article compares the work of a biographer with the work of an archaeologist who verifies the sources and reconstructs the whole on the basis of the background and contexts of time and place. In the biographer's work, however, he notices one more element: research subjectivity, which in a world filled with nostalgia, we are not able to negate or eliminate.
\end{abstract}

KEY WORDS: biographical writing, representation, nostalgia, archeology of ruins, memory studies

Potrzeba odwagi, aby w obliczu wiedzy o skomplikowanych mechanizmach pamięci, wspominania i zapominania (nazywanej memory studies, pamięciologią lub pamięcioznawstwem, zob. Saryusz-Wolska, 2009; Radstone, 2008, a może ładniej, bo metaforycznie i literacko archeologią pamięci, a nawet archeologią ruin, zob. Donato, 1986) podejmować trud poszukiwań, wykopalisk, rekonstrukcji, budowania historycznej (tu: biograficznej) narracji. Podejmować rolę poręczyciela, tego, który daje rękojmię prawdy przeszłości, niewłasnego doświadczenia, cudzego losu.

Być może trzeba odwagi jeszcze większej, aby opuścić bezpieczną przestrzeń gabinetu badacza, zrezygnować z przywileju profesjonalnego egzegety słów. I sięgnąć do własnego doświadczenia przeszłości, swojej, najbardziej indywidualnej, historii, odtwarzania z pamięci okruchów codzienności, zdziwienia ponowną lek- 
turą i odnawianiem dawnych znaczeń. Wreszcie, aby rozpoznać i zaakceptować pułapkę nostalgii.

Oto bowiem w poszukiwaniu śladów nieżyjących pisarzy/artystów dotykam ściany milczenia albo przemilczeń, niepamięci, kreacji i odkształceń, obcuję z obrazem i anegdotą - archeologicznym fragmentem pozbawionym narracyjnej ciągłości. Nieustannie przekonuję się o niewczesności własnych pytań i prób rozszyfrowania tropów, o zaniedbaniu i opóźnieniu, przecież niejedynym, nas, historyków literatury, teatru, sztuki, zajętych rozważaniem metodologii, teorii, konwencji i struktur, zajętych uniwersytecką krzątaniną - niespiesznych kochać zapomnianych, porzuconych twórców...

Mylne tropy i pozacierane ślady, wędrówka w labiryncie faktów, domysłów, symboli i znaczeń - nic nie daje gwarancji sukcesu. Jako niewczesna biografka w obliczu fragmentu i porozrywanej narracji nie mam nad kolekcją anegdot i obrazów tej przewagi, jaką daje czasowy dystans, a wraz z nim znajomość dziejowych wydarzeń, chronologii, kulturowych kontekstów, a także umiejętność konstruowania klasycznych opowieści (do których Hyden White zaliczył tragedię, komedię, satyrę i romans, zob. White, 1973). Przybieram zatem pozy sędzi, koneserki, kuratorki. Idealizuję i tworzę fantazmaty. Uczestniczę w rytuałach upamiętniania. W przypadku odpomnianej w latach dziewięćdziesiątych ubiegłego wieku, po ponad pół wieku milczenia, poetki Zuzanny Ginczanki, ją samą i jej tragiczny los umieszczam w muzeum, w panteonie mitologicznych postaci, rozważając najbardziej atrakcyjne etykiety: współczesna Sulamita, Rachela albo Gwiazda Syjonu; rosyjska Żydówka - polska poetka; muza przedwojennej ostatniej cyganerii; podopieczna Juliana Tuwima, przyjaciółka Witolda Gombrowicza; ofiara i symbol Holokaustu; prekursorka nowej kobiecej poezji, ikona rodzimego feminizmu...

Ów szczególny antykwaryzm, owo adorowanie przeszłości, karmienie się tym, czego nie ma, badacze określają jako usable past - historia użyteczna dla naszej teraźniejszości (zob. Commager, 1967; Zaleski, 1996). W odniesieniu, co prawda, do współczesnej literatury, ale adekwatnie również do form dokumentalnych, w tym biografii, zauważył Marek Zaleski w rozprawie Formy pamięci:

[Ś]wiat przeszłości opowiedziany za pomocą obrazów i anegdot wraca jako echo estetyczne, zostając jednocześnie zawłaszczony pod pretekstem ratowania substancji spod władzy niszczycielskiej historii. Postaci, rzeczy i zdarzenia tracą swój rzeczywisty status ontologiczny i zmieniają się w znaki, stają się pożywką i materiałem zabiegów mitotwórczych. (1996, s. 216)

Fragmenty archeologiczne, które zastępują rzeczywistość, są ahistoryczne, a wręcz - jak chce Zaleski - antyhistoryczne, prowokując tym samym sposób lektury unieważniający dokument, przesuwając go w stronę literackiej fikcji. Tak właśnie - niepostrzeżenie - wyeliminowany zostaje z przeżywania przeszłości ból na rzecz skupionej głównie na estetyce kontemplacji muzealnej ekspozycji, widowiska teatralnego pozbawionego elementów dramatycznych. 
Im bardziej staramy się przeszłość ocalić, tym bardziej - paradoksalnie - staje się ona obca i niezrozumiała. Wiedziona impulsem i chęcią pamięci, literatura zamiast obrazu przeszłości tworzy sztuczne raje, świat kolekcjonera sentymentalnych pejzaży i barwnych anegdot. I autor, i jego czytelnicy poruszają się w nim niczym grupa turystów z przewodnikiem [...]. (Zaleski, 1996, s. 216)

Ponownie, tym razem symbolicznie, uśmiercamy to jedno, wybrane spośród wielu, istnienie. Pisze autor Form pamięci: „Arsenał kulturalnych i estetycznych filtrów sprawia, że to, co rzeczywiste, zmienia się w pozór, miejsce empatii zajmuje wreszcie obojętność (bo życie jest akcją, a nie kolekcją, a świat bez bólu staje się w końcu obojętny)" (Zaleski, s. 27).

Antidotum na owo ponowne uśmiercanie jest zatem działanie - akcja, narracja, mozolne konstruowanie ciągu wydarzeń. Snujemy opowieści, wypełniamy puste miejsca, przemycamy elementy własnych i cudzych historii, indywidualnych i zbiorowych, angażujemy wyobraźnię, aby czyjś zapomniany, dopiero co odpominany los uczynić funkcjonalnym elementem teraźniejszości. Sprzyja nam przy tym ów odczuwany powszechnie przymus opowiadania (niem. Lust zu fabulieren), skłonność bowiem do budowania narracji jest cechą nie indywidualną, lecz gatunkową, co podkreślają pamięcioznawcy (zob.: Augé, 2009; Zimand, 1989; Welzer, 2009). „Niezbywalną [...] właściwość homo sapiens stanowi to, że jest gatunkiem opowiadającym i słuchającym opowieści. [...] można powołać się na fakt, iż nie znamy ani jednej kultury, która obchodziłaby się bez opowiadania” (Zimand, 1989, s. 14). I Harald Welzer: „Dzięki procesowi memory talk, czyli dzięki wspólnej praktyce snucia wspomnień w toku konwersacji, jak również dzięki każdej przeczytanej książce czy obejrzanemu filmowi, nauczyliśmy się, że prawidłowa historia ma swój początek, środek i koniec" (2009, s. 40).

I wreszcie snuciu opowieści sprzyja nostalgiczna wrażliwość, znów jako genetyczna cecha charakteryzująca nas zamieszkujących współczesność. „Tęsknię, więc jestem" - być może to ta jedyna myśl tylko jeszcze, która wśród potłuczonych fragmentów pamięci łączy wszystkich nas - biografów, egzegetów, czytelników, turystów, artystów, badaczy... O zbiorowej epidemii nostalgii sporo pisze Svetlana Boym, odmawiając postrzegania towarzyszących jej emocji jako jednostki chorobowej diagnozowanej indywidualnie, proponując zaś myślenie w kategoriach nostalgicznego symptomu naszych czasów, więcej nawet, bo dyktatury światów rzeczywistych, fantastycznych i wirtualnych, zawłaszczających każdą naszą wolną przestrzeń i manipulujących nie tylko naszym czasem. Jak twierdzi Boym:

Nostalgia może być kreacją poetycką, indywidualnym mechanizmem przetrwania, praktyką kontrkulturową, trucizną bądź lekiem. To od nas zależy, czy przyjmiemy na siebie odpowiedzialność za naszą nostalgię i nie pozwolimy innym, by ją dla nas ,prefabrykowali”. (2014, s. 340)

Zatem aby uniknąć owego „dyskomfortu nostalgii”, uwięzienia w cudzej wyobraźni, obcej mi albo fałszującej moje strzeżone przecież pilnie ,,ja”, próbuję odwoływać się do własnej nostalgicznej wrażliwości i mniej jako historyczka literatury, 
bardziej jako odczuwająca niewygodę własnego miejsca i czasu oraz własnej w nich obecności, chcę mówić o empatii i wzniosłości, które pozwalają przekształcić kontemplację kolekcji we współodczuwanie wywołujące wzruszenie i sprawiające ból. Jeszcze inaczej mogłabym, za inspirującym w sposób niezwykły W. H. Audenem, zadeklarować ujawnienie drzemiących we mnie „duszy historyczki” $i$ „duszy poetki”. Bo przeszłość będąca poza mną i domagająca się racjonalnego opisu jest jednocześnie czymś bliskim, przeżywanym, a niespełnionym. Brytyjski historyk George Macaulay Trevelyan pisał:

Poezja historii skrywa się w tym graniczącym niemal z cudem fakcie, że raz kiedyś, tutaj, w znajomym nam czasie i w równie znajomej przestrzeni, po tym kawałku ziemi spacerowały jakieś kobiety i jacyś mężczyźni równie rzeczywiści jak my dzisiaj, że coś sobie myśleli, coś czuli, a teraz to wszystko przepadło: pokolenie mija za pokoleniem, znika bez śladu, tak jak my sami wkrótce znikniemy niczym duchy spłoszone pianiem koguta o świcie. (Zaleski, s. 30)

\section{ŚWIADKOWIE}

Wobec takich emocji nie można nie zadać pytania o wiarygodność wspomnień świadków: przyjaciół, znajomych, przypadkowych obserwatorów. O dokumentacyjną wartość rozmów. Nie ma „obiektywnych” relacji, że za każdym obrazem, każdym słowem znajduje się ktoś, kto ma prawo do własnej prawdy, do własnej wersji wydarzeń, do kreowania „momentów wartościujących” (Welzer, 2009, s. 49), zbudowanych z rzeczywistego przeżycia, ale i z powszechnie obowiązujących modeli etycznych. Podzielam jednak wątpliwości i ostrożność Romana Zimanda, który napisał: „Chodzi mi więc nie o to, by unieważnić w tej sferze problem prawdy i fałszu, lecz by pokazać, że do owej prawdy znacznie trudniej jest dotrzeć, niż się to na ogół przypuszcza" (Zimand, 198, s. 8).

Jak pisać czyjąś biografię, wydobywać z zapomnienia cudzy los, z góry zakładając ograniczenie zaufania do ludzkiej pamięci? Oraz, za Zimandem, bacznie przyglądając się czterem rodzajom nacisków wywieranych na autorach relacji: „emocjom, potrzebie snucia refleksji wyjaśniającej, potrzebie opowiadania - i ostatnie, choć nie najmniej ważne - egotyzmowi" (Zimand, s. 13). Przyjmując koncepcję najprostszą, biografa jako montażysty wspomnień, wystarczyłoby zebrać wszystkie relacje, do minimum ograniczając ingerencję cięć i komentarzy, decydując się jedynie na konfrontację świadectw, dokumentów, wspomnień ukazujących to samo miejsce i czas; wnioski pozostawiając w gestii czytelnika. Ale montaż zdarzeń może być pozbawiony ciągłości przyczynowo-skutkowej, nadto nazbyt przypominać owo wcześniej omówione muzeum anegdot i obrazów. Można zatem inaczej, mianowicie zastosować strategię śledztwa i na drodze dedukcji ustalić najbardziej wiarygodną wersję tego, co się wydarzyło. Ale stąd już tylko krok do najbardziej niebezpiecznego działania: montażu skojarzeń, który może stać się montażem in- 
synuacji, wskazywania winnych. Gdy więc następuje próba rozstrzygnięcia wątpliwości, odkrycie konfabulacji albo nieprawdziwość alibi, czy mam prawo do ocen, cenzury? A jeśli to ja popełniam błąd? Jeśli to moje alibi - badaczki, biografki - nie wystarczy, aby tłumaczyć się z oskarżeń?

Zostaję zatem wciąż z tymi samymi pytaniami, zadawanymi sobie i o siebie-biografkę: o pamięć, która dotyczy nieprzeżytego, o nieadekwatność moich doświadczeń zarówno w odniesieniu do losu głównego bohatera rozważań, jak zapoznanych opowieści świadków; o to, jak sprostać przeżyciom kobiety zaszczutej, zamordowanej w bezsensowny, niemieszczący się w jakichkolwiek standardach sposób; o to, co nawet jeśli da się pomyśleć, nie jest możliwe do wyrażenia, biorąc pod uwagę niszczycielską siłę języka; a jeśli, to z nieustannym naruszaniem zasady decorum.

Zadając (sobie) te pytania, wracam do eseju Davida Lowenthala, w którym autor cytuje niezwykłej urody słowa D. J. Carne Ross:

Głównym powodem, że przeszłość jest tak słaba, jest nadzwyczajna moc teraźniejszości. [...] Usiłowanie, by prawdziwie „zrozumieć przeszłość”, podobne jest do wyglądania o zmierzchu z okna jasno oświetlonego pokoju. Wydaje się, że coś jest w ogrodzie, widać zarys drzew kiwających się na wietrze, ślad ścieżki, być może nawet błysk wody. A może jest to tylko obraz namalowany na szybie, tak jak Furie ze sztuki Eliota? Może za oknem nie ma niczego, a jedyna rzeczywistość to ten oświetlony pokój? (Za: Lowenthal, 1991, s. 7)

Gdy rodzi się dysonans między tym, co mogę uchwycić pojęciowo, zrozumieć, a tym, co tak naprawdę zaszło, moje obolałe nostalgiczne ,ja” angażuje owładniętą nieuleczalną tęsknotą wyobraźnię. Skoro, jak twierdził Immanuel Kant, czas jest nie do odzyskania (za: Zaleski, 1996, s. 17), to nostalgia żywić się musi nie pamięcią, lecz wyobraźnią właśnie, ta zaś wymaga nieustannego powtarzania, rozpamiętywania szczegółów odkrywanych w procesie alienacji z teraźniejszości i zakorzeniania w wyimaginowanym świecie. Ułomnym, bo zbudowanym z narracyjnych matryc i znanych skądinąd klisz, z tego, co oswojone i zaakceptowane. Bo niby jak opowiedzieć to, co nierozpoznane, nieporównywalne z niczym, obce? Dlatego elementy scenografii i fragmenty z innych, znanych mi już historii, przerabiam i włączam do opowieści o mojej bohaterce, decydując się na przyczynowo-skutkowy montaż wspomnień.

W tym sensie zatem biografia nie jest narracją o przeszłości, lecz wariacją na temat czasu, w jakim powstała. David Lowenthal pisał, sugerując odsiecz, jaką jest nostalgiczna wzniosłość, która podpowiada znane już, najczęściej zmitologizowane narracje, że

przeszłość, z powodów zasadniczych, jest niepewna, co zmusza nas do nerwowego udawania, że była właśnie taka, za jaką ją uważamy. Chcemy mieć pewność, że dzień wczorajszy był równie rzeczywisty, jak dzisiejszy: obciążamy się więc bez reszty relikwiami przeszłości, namacalnie potwierdzającymi pamięć i historię. Lubimy sobie wyobrażać, że ci, którzy kiedyś żyli, już wówczas chcieli, byśmy wiedzieli, jak bardzo ich życie było prawdziwe. (1991, s. 29) 
I tak na przykład historia Zuzanny Ginczanki rysuje się w tej perspektywie jako repetycja wcześniej ustalonego wzorca, jako opowieść, którą można umieścić w kilku co najmniej ramach kulturowych (jak choćby wielokulturowość, emancypacja, skamandryckość vs. katastrofizm, Holokaust), na kilku poziomach percepcji: w akademickim dyskursie historycznym, w rozmaitych formach kultury i gatunkach sztuki - w literaturze, filmie, fotografii, malarstwie, grafice, ale także w potocznym rozumieniu historii, które karmi się między innymi wymienionymi wcześniej sposobami rozszyfrowywania rzeczywistości. Odkryte fragmenty zrujnowanych obrazów i anegdot łączą się i uzupełniają, oświetlają wzajemnie zgodnie z regułami owych wzorców. Nie ma innej możliwości uspójnienia i zrozumienia przeszłości, skoro nawet, jak udowadnia Marek Zaleski, myślenie o własnym losie, pisanie o sobie, konstruowanie autobiografii nie jest wolne od owego nieustannego rzutowania na znane schematy fabularne, od odwoływania się do oficjalnego obrazu historii. Wyrazistym przykładem jest tu Przyczynek do biografii Jana Kotta (1990), który,

kiedy pisze o grozie życia pod okupacją, odwołuje się do powieści Malraux, rewizję swojej koleżanki z konspiracji zamienia w scenę z teatru Brechta i odwołuje się do teatralnej Brechtowskiej terminologii, gdy opowiada o swojej ucieczce do Krakowa, przywołuje Chestertona, kiedy pisze o pogrzebie starego komunisty, sięga po aluzje szekspirowskie, Henryka Hollanda przyrównuje do Jacka Woszczerowicza grającego Ryszarda III. Nade wszystko jednak modeluje swoją narrację wedle wyraźnych reguł gatunkowych: czyni siebie samego bohaterem powiastki filozoficznej i teatru marionetek jednocześnie. W przedmowie do amerykańskiego wydania - i we wstępie do garści notatek [...] przedrukowanych w „Ex Librisie” - pisze wprost o tym, że przypadłaby mu rola i los dwudziestowiecznego Kandyda. Dla Kotta opowiedzieć oznacza strawestować, opowiedzieć przez powtórzenie, parafrazę, aluzję do czegoś, co już z doskonałym skutkiem opowiedział ktoś inny. Samo życie doczekuje się u niego rozmaitych definicji, ale życie opowiedziane to zawsze la pièce bien faite. (Zaleski, 1996, s. 76)

Również Harald Welzer zgłębia ten temat, skupiając się na obrazach filmowych, które, za Joanną Burke, autorką książki An Intimate History of Killing (1999), odnajduje we wspomnieniach żołnierzy biorących udział w wojnie w Wietnamie. W swoich rozważaniach Materiat, z którego zbudowane sa biografie, Welzer cytuje badaczkę: „Każda interpretacja dzienników, listów i autobiografii wskazuje na to, jak przejmujemy (i przepisujemy) z literackich i filmowych przedstawień kobiet i mężczyzn, i to jeszcze zanim wojna w ogóle się zacznie (2009, s. 42).

Wydaje się, że oto kino tworzy historie poszczególnych osób w znacznie większym stopniu, aniżeli uczestnicy zdarzeń są w stanie indywidualizować własny los. Bo być może w nieludzkim czasie pozbawionym etycznych reguł $i$ we wrogiej przestrzeni destrukcji potrzeba szczególnej wspólnoty? Języka, narracji, kulturowego doświadczenia?

To jednak nie wszystko, bo moja nostalgiczna empatia powoduje, że mówiąc, pisząc o coraz bliższych mi twórcach, przemycam też opowieść o sobie, kreślę własny portret, ożywiam moją przeszłość, uruchamiam wspomnienia i doświadczenie - także 
to lekturowe. Tworzę, potwierdzając słowa Jeana Starobinskiego, biografię „tego, kto właśnie trzyma w ręku pióro" (za: Zaleski, 1996, s. 75). Mimo autentycznego pragnienia przezroczystości, które jest ze mną od zawsze i w każdej życiowej sytuacji, nie tylko teraz, gdy piszę... Wiedzieli o tym filozofowie i badacze - Leszek Kołakowski: „W całym wszechświecie człowiek nie potrafi odnaleźć studni tak głębokiej, by pochylając się nad nią, nie odkrył na dnie swojej własnej twarzy" (Zaleski, 1996); i James Olney: „Człowiek nieustannie przeszukuje wszechświat w nadziei dotarcia do praw i form będących nie jego dziełem, by zawsze natknąc się w końcu na odbicie własnej twarzy, niczym w znanym przedstawieniu twarzy księżyca, w której rozpoznaje znajome rysy" (Zaleski, 1996).

Skoro nie mam szans na przezroczystość, to muszę zdobyć się na uczciwość i mówiąc „ona/on”, powiedzieć także ,ja”. To kolejna pułapka biografizmu, w której rekonstruktora i tłumacza czyjegoś życia dotyczą wszystkie cztery zastrzeżenia poczynione przez Romana Zimanda w odniesieniu do relacji świadków. I więcej jeszcze, zbytnie eksponowanie własnej historii, własnej twarzy i własnego egotyzmu grozi niezrozumieniem i ponowieniem pytania o reprezentację: Jakie mam prawo, aby opowiadać cudze życie? Jakie mam prawo, aby rozważać decyzje, ujawniać tajemnice, komentować pozacierane ślady, puste miejsca i palimpsesty? Skoro to wszystko przepływa przeze mnie, jest moim subiektywnym punktem widzenia, odczuwania i rozumienia... Jest moją teraźniejszością...

To zatem empatia i wzniosłość, indywidualne doświadczenie świadków zdarzeń oraz autora biografii, a także doświadczenie zbiorowe zapisane w tradycji określonej kultury składają się na opowieść biograficzną, zawsze jednak, jak chce Claude Lévi-Strauss, historię ,słabą”, bo poddaną deformacyjnej presji zarówno indywidualnych, jak i zbiorowych mitologii. Ale ów epitet „słaba” okazuje się na tyle pojemny, aby definiować za jego pomocą także sam proces poznania będący udziałem biografa - akt niepewny, kruchy, ułomny, bo wskazujący „na niezdolność myśli i języka do pełnego uchwycenia bytu, utratę przez myśl jej mocy przed-stawieniowej jako zdolności do kontroli, panowania, zawłaszczania bytu, czy też, w wersji mniej radykalnej, jako możliwości dania wyczerpującego opisu rzeczywistości” (Zawadzki, 2009, s. 16).

Zatem lektura biografii zawsze będzie mylna, błędna, niepełna. Obraz przeszłości, powiększany w poszukiwaniu szczegółów jest - paradoksalnie - coraz mniej wyraźny. Jak w słynnym filmie Michelangelo Antonioniego z 1966 roku Blow up (Powiększenie), którego punktem dojścia jest przekonanie, że fotografia (traktowana jako dokument, nawet gdy eksponuje się jej walory estetyczne) wcale nie wyjaśnia świata, wręcz przeciwnie, ów świat coraz bardziej zaciemnia. I jak w opowiadaniu Julio Cortazara Babie lato (1954), będącym inspiracją dla reżysera, gdzie decyzja fotografa, decyzja estetyczna, której konsekwencją jest kadrowanie, powoduje usunięcie najważniejszych, kluczowych dla zrozumienia opowieści elementów rzeczywistości i w perspektywie głównego bohatera (fotografa) staje się wyłącznie częścią onirycznej wyobraźni: domysłów, wariacji, odkształceń. „Im bardziej staramy się przeszłość ocalić, tym bardziej - paradoksalnie - staje się obca i niezrozumiała" - pisze Marek Zaleski (Zaleski, 2009, s. 215). Być może jedyną nadzieją w tej nieustannej przepy- 
chance przeszłości i teraźniejszości jest przyszłość. „Prawdziwi czytelnicy, ci, którzy docierają do sensów ukrytych dzieła, przychodzą później...” - twierdzi przy innej okazji Zaleski (Zaleski, 2009, s. 97). I ja bardzo chciałabym mu wierzyć, że jest właśnie tak, że kruchość przeszłości i wszędobylskość teraźniejszości kiedyś nareszcie, w przyszłości, zrodzi prawdziwy, choć wcale niefotograficzny (czytaj: dokumentalny, mimetyczny) obraz człowieka, bohatera odtwarzanej przeze mnie biografii, ujawniając jego skryte sensy, dzisiaj zamazane i wciąż nieczytelne, wciąż stawiające opór nie tylko mojej myśli i nie tylko moim emocjom. Zaleski pisze dalej:

Z tego oporu rodzi się dopiero znaczenie prawdziwe. Dopiero wtedy spoza tekstu prześwitywać [zacznie] rzeczywistość, która zawsze umyka całkowitej symbolizacji i nie daje się raz na zawsze zamienić $\mathrm{w}$ tekst. $Z$ tego rodzaju lektury rodzi się długo oczekiwany efekt. $Z$ tego rodzaju lektury rodzi się długo oczekiwany efekt: szok rozpoznania - owo głębokie poczucie bliskości i obcości zarazem, niczym smak starego wina, które lejemy w nowe dzbany [...]. (2009, s. 97)

\section{BIBLIOGRAFIA}

Auden, W. H.

1988 Ręka farbiarza i inne eseje. Wybór M. Sprusiński, J. Zieliński. Warszawa: PIW.

Augé, M.

2009 Formy zapomnienia. Rozdział: Życie jako opowieść. Przekł. A. Turczyn. Kraków: Universitas.

Boym, S.

2014 Dyskomfort nostalgii. W: K. Kończal (red.), (Kon)teksty pamięci. Antologia. Warszawa: Narodowe Centrum Kultury.

Commager, H. S.

1967 The Search for a Usable Past and Other Essays in Historiography. Nowy Jork: Alfred A. Knopf.

Donato, E.

1986 Ruiny pamięci: fragmenty archeologiczne i artefakty tekstowe. Przekł. D. Gostyńska. Pamiętnik Literacki, 3, 319-339.

Lowenthal, D.

1991 Przeszłość to obcy kraj. Przekł. I. Grudzińska-Gross, M. Tański. Res Publica Nova, 10(200), 142-151.

Radstone, $\mathrm{S}$.

2008 Memory Studies: For and Against. Memory Studies, 1, 31-39.

Saryusz-Wolska, M.

2009 Wprowadzenie. W: M. Saryusz-Wolska (red.), Pamięć zbiorowa i kulturowa. Wspótczesna perspektywa niemiecka. Kraków: Universitas.

Welzer, $\mathrm{H}$.

2009 Materiał, z którego zbudowane są biografie. Przekł. M. Saryusz-Wolska. W: M. Saryusz-Wolska (red.), Pamięć zbiorowa i kulturowa. Wspótczesna perspektywa niemiecka. Kraków: Universitas.

White, $\mathrm{H}$.

1973 Metahistory. The Historical Imagination in the Nineteenth-Century Europe. Baltimore: John Hopkins University. 
Zaleski, M.

1996 Formy pamięci. O przedstawianiu przeszłości w polskiej literaturze wspótczesnej. Warszawa: Instytut Badań Literackich PAN.

Zawadzki, A.

2009 Literatura a myśl słaba. Kraków: Universitas.

Zimand, R.

1989 Rozmowa z... - dokument czy literatura. W: R. Zimand, Czas normalizacji. Szkice czwarte. Londyn: Aneks.

BIOGRAPHICAL WRITING AS ARCHAEOLOGY OF RUINS

Sum mary

Biographical writing, thrown out by the methodologies of the twentieth century outside the area of humanities research, returns - sometimes under the name biography to the canon of humanities research along with the field called memory studies (but also along with gender studies and cultural anthropology). This return is not devoid of dilemmas that relate to: 1) a biographer as a representative of the hero of the biography and as subjected to his own experience of nostalgia of the subjective "storyteller"; 2) accounts of witnesses. Two concepts of research roles can be adopted. First of all - a biographer as a memories editor, who collects all accounts, minimizing the interference of cuts and comments, deciding only to confront testimonies - documents - memories, showing the same place and time; leaving applications to the reader. But the assembly of events may be devoid of cause-and-effect continuity, and it is too much like the museum of anecdotes and paintings discussed above. Secondly, therefore - an investigation strategy can be used and the most credible version of what happened can be determined by deduction. But from here it is only a step to the most dangerous action: the assembly of associations, which can become a montage of innuendo, indicating the guilty ones. With the feeling that the more we want to brighten the reconstructed image, the more details we demand, the more it obscures the whole, loses its contours. Following Roman Zimand, I also point to other threats to biography that concern "representation" - both for the writer and for witnesses. These are: emotions, the need for explanatory reflection, the need for storytelling (recognized as a genetic trait of the human race), egotism. Taking into account the above reservations and dilemmas in the article, I proposed the role of a biographer as an archaeologist who verifies the sources and reconstructs the whole based on the background and contexts of time and place. He leaves his work incomplete, with only the outlines of the whole. Complementary in the metaphor of ruins. 